\title{
Formatívne hodnotenie vo výučbe chémie
}

\author{
Mária Babinčáková1, 2 - Mária Ganajová ${ }^{1}$ - Ivana Sotáková ${ }^{1}$ \\ 'Department of Didactics of Chemistry, Faculty of Science, \\ Pavol Jozef Šafárik University in Košice, Moyzesova 11 Košice, Slovak Republic \\ ${ }^{2}$ Department of Teaching and Didactics of Chemistry, Charles University in Prague, \\ Faculty of Science, Albertov 6, 12843 Praha 2, Czech Republic \\ e-mail: maria.babincakova@upjs.sk
}

\section{Formative Assessment in Chemistry Education}

\section{Abstract}

The aim of the paper is to provide information on the possibilities of implementing a formative assessment in the teaching of chemistry in the 7 th grade of secondary school. Formative assessment tools for the topic of Mixtures were implemented in experimental groups by 5 teachers. Control and experimental groups were compared by a cognitive test consisting of 10 tasks focused on 4 levels of Bloom's revised taxonomy. Results were statistically evaluated.

Keywords: formative assessment; mixtures

Kl'účové slová: formatívne hodnotenie; zmesi

Subject-Affiliation in New CEEOL: Social Sciences - Education - School Education

DOI: 10.36007/eruedu.2020.1.006-012

\section{1 Úvod}

Slovenské školstvo je založené na normatívnych formách evaluácie uprednostňujúcich externú a sumatívnu evaluáciu vzdelávania. Tento záver je jednoznačne vyslovený v Správe o evaluácii a hodnotení vo vzdelávaní, ktorú o Slovenskej republike vypracovala v roku 2014 OECD (Shewbridge, Van Bruggen, Nusche, \& Wright, 2014). Hodnotiaci tím OECD upozornil na to, že hodnotenie žiakov na Slovensku nie je dostatočne formatívne, a že tu existuje silná potreba spätnej väzby pre žiakov, aby sa mohli zlepšovat' v učení. OECD navrhuje, aby sa do slovenského vzdelávacieho systému zaviedli prvky „formatívneho hodnotenia“, ktoré dokážu zachytit' nielen to, „čo“ a „, akým“ výsledkom sa žiaci učia, ale aj „ako“ sa učia (Shewbridge et al., 2014). Ako uvádza Orosová, Ganajová, Szarka, a Babinčáková (2019), sumatívne hodnotenie na slovenských školách prevláda nad formatívnym a 
využitie nástrojov formatívneho hodnotenia nepresahuje v priemere 30\%. Niektorí autori uvádzajú, že formatívne hodnotenie má mnoho pozitívnych vplyvov na učenie žiakov. Žiaci dosahujú lepšie výsledky, t. j. formatívne hodnotenie prispieva $\mathrm{k}$ zlepšeniu výkonov žiakov a celkovej kvalite vzdelávania (Bell \& Cowie, 2001; Black \& Wiliam, 1998; Wiliam, Lee, Harrison, \& Black, 2004). Formatívne hodnotenie rozvija nielen kompetenciu naučit' sa učit' (t. j. žiaci sú schopní poučit' sa zo svojich chýb, sami vyhodnocujú výsledky procesu učenia a navrhujú riešenia pre zlepšenie svojich výkonov), ale tiež kompetencie sociálne a personálne (Myhill \& Warren, 2005).

\section{Teoretické pozadie}

Školské hodnotenie zahŕňa všetky hodnotiace procesy učitel'ov a žiakov, ktoré sú súčast'ou vyučovania a učenia, a ich hlavným ciel'om je zvyšovat' efektivitu vyučovania, zlepšovat' priebeh žiakovho učenia a viest' žiakov k lepšiemu porozumeniu a učebným činnostiam (Slavík, 1999).

Rozoznávame dva fundamentálne typy hodnotenia: sumatívne a formatívne hodnotenie. Sumatívne hodnotenie (SH) sumarizuje dôkazy, teda sa väčšinou aplikuje na konci časti vyučovacieho procesu. Poskytuje informácie o pokroku žiakov a je aplikované najmä formou testov (Baird, Andrich, Hopfenbeck, \& Stobart, 2017; Harlen, 2000). Formatívne hodnotenie na druhej strane poskytuje hodnotenie počas vyučovacieho procesu (Scriven, 1967). Mnoho autorov sa venuje vzt'ahu medzi sumatívnym a formatívnym hodnotením. Taras (2005) zdôrazňuje, že formatívne hodnotenie má nasledovat' po sumatívnom hodnotení. Sambell, McDowell, a Montgomery (2012) vyzdvihuje, že oba typy hodnotenia majú byt' zdrojom pre učenie a Siweya a Letsoalo (2014)a selection criterion was executed on the 1687 sample, after which 1519 cases remained for the analysis. The study revealed a statistically significant SLR model, suggesting that formative assessment (FA poukazujú na to, že formatívne hodnotenie môže predvídat' sumatívne hodnotenie.

Educational Testing Service (ETS) v spolupráci s Wiliam (2007) predstavili program „Keeping Learning on Track ${ }^{\circledR}$ Program“ s 5 stratégiami formatívneho hodnotenia:

- zdiel'anie učebných výsledkov (sharing learning expectations),

- kladenie otázok (questioning),

- spätná väzba (feedback),

- sebahodnotenie (self-assessment),

- a rovesnícke hodnotenie (peer assessment) (Bennett, 2011),

pričom Formative Assessment Classroom Techniques' (FACTs), alebo nástroje formatívneho hodnotenia, patria medzi nich (Srivastava, Mishra, \& Waghmare, 2018). FACTs sú malé aktivity formatívneho hodnotenia, ktoré môžu poskytnút' krátky opis a spätnú väzbu z hodiny nie len učitel'ovi, ale aj žiakovi. Medzi takého FACTs patrí napríklad KWL karta, predikčná karta, Frayer model, kontrolný zoznam, myšlienková mapa, lístok pri odchode a iné (Keeley, 2008; Szarka, 2017). 


\section{Predikčná karta}

Je to hodnotiaci nástroj kedy žiak musi rozhodnút' o pravdivosti vybraných tvrdení k danej téme. O pravdivosti rozhoduje na začiatku ale aj na konci vyučovacej hodiny (Hubbard, Potts, \& Couch, 2017; Yüksel \& Gündüz, 2017).

\section{KWL karta}

Je to trojkrokový proces: na začiatku hodiny žiak napíše, čo už o danej problematike vie $(K)$ a čo by chcel vediet' $(W)$. Na konci hodiny napiše, čo sa naučil $(L)$ (Ogle, 1986).

\section{Frayer model}

Je to štvorec rozdelený na štyri časti, pričom každá čast' reprezentuje inú oblast', ktorá sa týka daného pojmu alebo frázy:

- definícia,

- fakty alebo charakteristiky,

- príklady,

- proti príklady (Frayer, Fredrick, \& Klausmeier, 1969; Wickens \& Parker, 2019).

\section{Lístok pri odchode}

Listok pri odchode, minútový lístok alebo tiež 3-2-1 karta je nástroj, kedy sa od žiakov vyžaduje napisat' 3 hlavné alebo najdôležitejšie body, ktoré sa na hodine naučili, 2 informácie ktoré považujú za najzaujímavejšie a 1 otázku, ktorú k danej problematike stále majú (He, 2019; Wilson, 1986).

\section{Kontrolný zoznam}

Hlavnou úlohou tohto nástroja je identifikovat', ktoré úlohy boli, respektíve neboli počas vyučovacej hodiny splnené (Purwanti, 2015). Na identifikáciu sa väčšinou použiva škála (5 bodová, 3 bodová, 2 bodová) (BCIT, 2010; Ma et al., 2012).

\section{Myšlienková mapa}

Pojmová alebo myšlienková mapa je diagram, ktorý pomáha žiakom organizovat' a vizualizovat' ich poznatky. Žiaci napíšu na papier pojmy a vytvárajú medzi nimi vzt'ahy (Champagne, Klopfer, Desena, \& Squires, 1981; Pendley, Bretz, \& Novak, 1994).

\section{Charakteristika výskumu}

V rámci našej práce sme si stanovili výskumnú otázku:

- Ako implementácia formatívneho hodnotenia pomocou FACTs ovplyvní výkony žiakov na kognitívnej úrovni?

Z nej nám vychádzala aj naša hypotéza: Žiaci experimentálnej skupiny dosiahnu lepšie výsledky v kognitívnom teste ako žiaci kontrolnej skupiny.

Aby sme získali odpoved' na uvedenú otázku, pomocou metódy kváziexperimen- 
tu sme realizovali predvýskum. V tomto predvýskume 5 učitel'ov začleňovalo FACTs do 10 vyučovacích hodín chémie (Tabul'ka 1) v 7. ročníku základnej školy v tematickom celku „Zmesi“. Každý učitel' učil kontrolnú aj experimentálnu skupinu. V experimentálnej skupine sa vyučovalo s nástrojmi FACTs, v kontrolnej skupine sa učilo bez týchto nástrojov. V predvýskume bolo zapojených 202 žiakov z 5 základných škôl, z toho 75 (37.1\%) chlapcov, 80 (39.6\%) dievčat, 47 (23.3\%) žiakov neznámeho pohlavia. V experimentálnej skupine bolo 105 (52.0\%) žiakov a v kontrolnej skupine bolo 97 (48.0\%) žiakov.

Tabul'ka 1. Typy nástrojov FH použitých počas vyučovacích hodín

\begin{tabular}{ll}
\hline Hodina & Typ nástroja FH \\
\hline 1 & Predikčná karta \\
2 & Frayer model, kontrolný zoznam \\
3 & K-W-L \\
4 & Predikčná karta \\
5 & K-W-L \\
6 & Kontrolný zoznam \\
7 & Myšlienková mapa \\
8 & Listok pri odchode \\
9 & Predikčná karta \\
10 & Kontrolný zoznam \\
\hline
\end{tabular}

Na začiatku aj na konci výučby bol žiakom zadaný kognitívny test (pre-test, post-test), pozostávajúci z 10 položiek na 4 rôznych úrovniach Bloomovej revidovanej taxonómie (zapamätanie, porozumenie, aplikácia, analýza). Jednotlivé položky boli vytvorené Národným ústavom certifikovaných meraní vzdelávania (NúCEM), pričom test bol zostavený na základe spolupráce s učitel'mi zapojenými do výskumu. Výsledky post-testu boli štatisticky vyhodnotené.

\section{Interpretácia výsledkov}

Skóre post-testu kontrolnej a experimentálnej skupiny bolo porovnané a výsledky boli štatisticky vyhodnotené. $V$ analýze sa porovnávalo skóre celého testu, ale aj skóre skupín úloh zoskupených podl'a úrovne Bloomovej revidovanej taxonómie.

Výsledky post-testu boli najprv podrobené Kolmogorov-Smirnovmu testu normality rozloženia dát. Tie vykazovali $p<0.05$, preto sa pri následnom štatistickom spracovaní použivali neparametrické testy.

Priemerné skóre celého testu experimentálnej skupiny ( 5.3 bodov) bolo vyššie ako skóre kontrolnej skupiny (3.2 bodov). Chí-kvadrát testom na hladine významnosti $\alpha=0.05$ bol potvrdený signifikantný rozdiel medzi týmto skóre $(p<0.001)$.

Rovnako boli porovnávané aj výsledky úloh zoskupených podla úrovne Bloomovej revidovanej taxonómie. Pri všetkých sledovaných úrovniach (zapamätanie, 
porozumenie, aplikácia, analýza) bolo skóre experimentálnej skupiny vyššie ako skóre kontrolnej skupiny na hladine významnosti $\alpha=0.05$.

\section{Záver}

Výsledky predvýskumu prezentované v tomto príspevku ukazujú, že implementácia formatívneho hodnotenia zlepšuje výsledky žiakov na kognitívnej úrovni. Tieto závery sú vyvodené na základe štatistickej analýzy výsledkov kontrolnej a experimentálnej skupiny. $\mathrm{V}$ analýze sa porovnávalo skóre žiakov v post-teste, ktorý bol realizovaný po 10 hodinách s implementáciou nástrojov formatívneho hodnotenia. Štatistická analýza ukazuje, že tieto výsledky sú štatisticky významné $(p<0.001)$ nie len pre skóre celého testu, ale aj pre otázky zamerané na vyššie myšlienkové operácie, ako sú aplikácia a analýza. V d’alšej časti našej práce sa chceme zamerat' na overenie týchto výsledkov. Taktiež by sme chceli sledovat' postoje žiakov $\mathrm{k}$ takémuto typu hodnotenia ako aj názory a postoje učitel'ov.

\section{Pod'akovanie:}

Tento príspevok vznikol s podporou projektu „IT Akadémia - Vzdelávanie pre 21. storočie“ č. 312011 F057 a projektu VEGA č. 1/0265/17 „Formatívne hodnotenie vo výučbe prírodných vied, matematiky a informatiky“.

\section{Použitá literatúra}

Baird, J. A., Andrich, D., Hopfenbeck, T. N., \& Stobart, G. (2017). Assessment and learning: fields apart? Assessment in Education: Principles, Policy and Practice, 24(3), 317350. https://doi.org/10.1080/0969594X.2017.1319337

BCIT. (2010). Instructional Job Aid. In Developing Checklists and Rating Scales. Retrieved from http://www.northernc.on.ca/leid/docs/ja_developchecklists.pdf

Bell, B., \& Cowie, B. (2001). The characteristics of formative assessment in science education. Science Education, 85(5), 536-553. https://doi.org/10.1002/sce.1022

Bennett, R. E. (2011). Formative assessment: A critical review. Assessment in Education: Principles, Policy \& Practice, 18(1), 5-25. https://doi.org/10.1080/096959 4X.2010.513678

Black, P., \& Wiliam, D. (1998). Inside the Black Box: Raising Standards Through Classroom Assessment. Phi Delta Kappan, 80(2), 118-119. https://doi.org/10.1002/hrm

Champagne, A. B., Klopfer, L. E., Desena, A. T., \& Squires, D. A. (1981). Structural representations of students' knowledge before and after science instruction. Journal of Research in Science Teaching, 18(2), 97-111. https://doi.org/10.1002/tea.3660180202

Frayer, D. A., Fredrick, W. C., \& Klausmeier, H. J. (1969). A schema for testing the level of concept mastery. Madison: Wisconsin Research and Development Center for Cognitive Learning.

Harlen, W. (2000). Assessment in the inquiry classroom. In Foundations: A monograph for 
professionals in science, mathematics, and technology education. Inquiry. Thoughts, Views, and Strategies for the K-5 Classroom (Second). Retrieved from https://www.nsf. gov/pubs/2000/nsf99148/pdf/nsf99148.pdf

He, Y. (2019). Traffic Light Cards: a Cross and Modification Between the Minute Paper and Muddiest Point. College Teaching, 67(1), 70-72. https://doi.org/10.1080/87567555.2 018.1522612

Hubbard, J. K., Potts, M. A., \& Couch, B. A. (2017). How question types reveal student thinking: An experimental comparison of multiple-true-false and free-response formats. $C B E$ Life Sciences Education, 16(2), 1-13. https://doi.org/10.1187/cbe.16-12-0339

Keeley, P. (2008). Science Formative Assessment. Thousand Oaks: Corwin Press.

Ma, I. W. Y., Zalunardo, N., Pachev, G., Beran, T., Brown, M., Hatala, R., \& McLaughlin, K. (2012). Comparing the use of global rating scale with checklists for the assessment of central venous catheterization skills using simulation. Advances in Health Sciences Education, 17(4), 457-470. https://doi.org/10.1007/s10459-011-9322-3

Myhill, D., \& Warren, P. (2005). Scaffolds or straitjackets? Critical moments in classroom discourse. Educational Review, 57(1), 55-69. https://doi. org/10.1080/0013191042000274187

Ogle, D. M. (1986). K-W-L: A Teaching Model That Developes Active Reading of Expository Text. The Reading Teacher, 39(6), 564-570.

Orosová, R., Ganajová, M., Szarka, K., \& Babinčáková, M. (2019). Evaluation in natural science subjects in the current context of Slovak education. Scientia in Educatione, 10(1), 17-32. Retrieved from https://ojs.cuni.cz/scied/article/view/1320/1146

Pendley, B., Bretz, R., \& Novak, J. (1994). Concept Maps as a Tool To Assess Learning in Chemistry. Journal of Chemical Education, 71(1), 9-null. https://doi.org/10.1021/ ed071p9

Purwanti, T. T. (2015). The Implementation of Self-Assessment in Writing Class: A Case Study at STBA LIA Jakarta. TEFLIN Journal , 26(1), 97-116. https://doi.org/10.15639/ teflinjournal.v26i1/97-116

Sambell, K., McDowell, L., \& Montgomery, C. (2012). Assessment for Learning in Higher Education. In Assessment for Learning in Higher Education. https://doi. org/10.4324/9780203818268

Scriven, M. (1967). The Methodology of Evaluation. Washington, DC, USA: American Educational Research Association.

Shewbridge, C., Van Bruggen, J., Nusche, D., \& Wright, P. (2014). OECD Reviews of Evaluation and Assessment in Education Slovak Republic. https://doi. org/10.1787/9789264117044-en

Siweya, H. J., \& Letsoalo, P. (2014). Formative assessment by first-year chemistry students as predictor of success in summative assessment at a South African university. Chemistry Education Research and Practice, 15(4), 541-549. https://doi.org/10.1039/ c4rp00032c

Slavík, J. (1999). Hodnocení v současné škole: východiska a nové metody pro praxi. Portál.

Srivastava, T. K., Mishra, V., \& Waghmare, L. S. (2018). Formative Assessment Classroom Techniques (FACTs) for Better Learning in Pre-clinical Medical Education: A Controlled Trial. Journal of Clinical and Diagnostic Research, 12(9). https://doi.org/10.7860/ JCDR/2018/35622.11969 
Szarka, K. (2017). Súčasné trendy školského hodnotenia: Koncepcia rozvijajúceho hodnotenia. Komárom: KOMPRESS.

Taras, M. (2005). Assessment - Summative and formative - Some theoretical reflections. British Journal of Educational Studies, 53(4), 466-478. https://doi.org/10.1111/j.14678527.2005.00307.x

Wickens, C. M., \& Parker, J. (2019). Supporting Vocabulary Acquisition in Physical Education Settings. Journal of Physical Education, Recreation and Dance, 90(5), 16-22. https://doi.org/10.1080/07303084.2019.1580635

Wiliam, D. (2007). Keeping learning on track: Formative assessment and the regulation of learning. Making Mathematics Vital: Proceeding of the Twentieth Biennial Conference of the Australian Association of Mathematics Teachers, 20-34. Retrieved from https:// www.researchgate.net/publication/252646685_Keeping_learning_on_track_Formative_ assessment_and_the_regulation_of_learning

Wiliam, D., Lee, C., Harrison, C., \& Black, P. (2004). Teachers developing assessment for learning: impact on student achievement. Assessment in Education, 11(1), 49-65. https://doi.org/10.1080/0969594042000208994

Wilson, R. C. (1986). Improving Faculty Teaching: Effective Use of Student Evaluations and Consultants. The Jounal of Higher Education, 57(2), 196-211.

Yüksel, H. S., \& Gündüz, N. (2017). Formative and Summative Assessment in Higher Education: Opinions and Practices of Instructors. European Journal of Education Studies, 3(8), 336-356. https://doi.org/10.5281/zenodo.832999

Jazyková korektúra: PaedDr. Jaroslav VInka, PhD. 